\section{PP-673 ウサギ陰茎海綿体トーヌス調節におけ} るアルキナーゼの役割

\section{東京医科齿科大学 医学部尿路生殖機能学" 東京医} 科齿科大学 生体材料工学研究所 ${ }^{2)}$

增田 均",矢野 雅隆", 酒井 康之", 川野圭三”

木原 和德", 東 洋"

【目的】陰茎海綿体トーヌス維持に、内皮由来の NO が重要であ る事は既に報告した。アルギナーゼはNOS と同様にLーアルギ ニンを基質とし、NOS と競合的に酒き、過㮃な NO 産生を防ぐ 役割を果たしている。今回我々は、陰茎海綿体トーヌス維持にお けるアルギナーゼの役割について検討した。【方法】鬼陰茟海綿 体を摘出し、一部はサボニンで海綿体内皮を化学的に剥離(剥離 群）し、その他は正常群とした。1）マグヌス法、2）アルギナー ゼの酵素活性を単位時間あたりの尿素の産生量で測定した。結 果】 $1 \mathrm{~g}$ の初期張力下で、正常群でのみNOS 阻害剤である L-

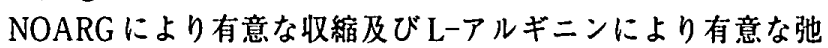
楥反応を認めた。また、正常群でのみアルギナーゼ阻害剤である $\mathrm{N}^{w}$-hydroxy-nor-L-arginine (NOHA)により有意な弛緩反応を認 め、同反応は、大量の L-アルギニン存在下では認められなかっ た。NOHA は L-NOARG による収縮反応を漫度依存性に抑制し た。アルギナーゼの醉素活性で、 $\mathrm{Km}$ 值は $1.83 \pm 0.15 \mathrm{mM}$ であり、 $\mathrm{V} \max$ は、2625 $\pm 321 \mathrm{pmol} / \mathrm{mg}$. 蛋白/分であった。NOHA は同 活性を最大 $95 \%$ 程度抑制し、L-NOARGは有意な影響を与えな かった。考察】鬼陰荎海綿体のトーヌスの維持に、内皮由来のア ルギナーゼがNOS と拮抗する形で関与している事がわかった。

\section{PP-674 海綿体神経龟気刺激時の至適条件の設 定一雑種犬を用いた検癿一}

\footnotetext{
群馬県立がんセンター”群馬大学 医学部 泌尿器科 学2) 館林擪生病院 ${ }^{3)}$

武井 智幸", 黒川 公平 ${ }^{2}$, 岡崎 浩 ${ }^{3}$, 鈴木 和浩"

鈴木 孝虫", 山中 英独"

（目的）前立腺全摘除術時に神経血管束を温存する場合, 客観 的な評価方法として術中の勃起神経電気刺激時の陰茎海綿体 内圧の測定がある。この電気刺激の至適条件について雑種犬 を用いて検討した（対象と方法）対象は雄雑種成犬 6 頭で平 均体重 $11.3 \mathrm{~kg}$ であった，フローセン，笑気による吸入麻䤃下 (自発呼吸)で下腹部正中切開し前立腺側方で海綿体神経を露 出, また陰茎包皮も切開して陰茥を露出した。陰荎海綿体や龟 頭球に刺入した針，また尿道に留留したバルーンカテーテル で，海綿体神経を単極電桯で種々の条件で電気刺激した時の 内圧の変化を測定した. (結果) 電流 $30 \mathrm{~mA}$ ，刺激幅 $0.2 \mathrm{~ms}, 15$ 秒間刺激で刺激周波数を $1 \mathrm{~Hz}$ から $20 \mathrm{~Hz}$ まで変化させた時, 6 $\sim 8 \mathrm{~Hz}$ 以上で内圧の上昇は一定となった。電流 $30 \mathrm{~mA}$, 刺激周 波数 $10 \mathrm{~Hz}, 15$ 秒間刺激で刺激幅を $0.05 \mathrm{~ms}$ から $1.0 \mathrm{~ms}$ まで変 化させた時, $0.1 \mathrm{~ms}$ 以上で充分な内压の上昇がみられた. 内压 測定部位では陰菱海綿体で最も大きな内圧上昇 $(50 \mathrm{mmHg}$ 以上)がみられたが，刺激を繰り返し行った場合には陰䒱海綿 体に囲まれた部位での尿道カテーテル湘定が安定していた。 (結詥) $30 \mathrm{~mA}, 10 \mathrm{~Hz}, 0.2 \mathrm{~ms}, 15$ 秒間で充分な刺激と考えられ

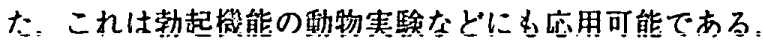

\section{PP-675 社会的ストレスによるラット性行動障 传および dehydroepiandrosterone (DHEA) の効果に関する検討}

\author{
金沢大学 医学部 泌尿器科 \\ 水野㽗,小松和人, 石浦募之, 中村靖夫, 長坂康弘 \\ 福島 正人,並木 幹夫
}

【目的】雄ラットの社会的ストレス後の栍行動変化および dehydroepiandrosterone (DHEA) の効果を検討した。【対象と方法】性行 動を確認済みの 10 週龄 SD 雄性ラットを Long-Evans 系ラットの コロニー内に導入し、1 日数分間、連踫 5 日間攻㹂を受けさせた。(社 会的ストレス) ストレス後、再度性行動を評価し：さらにストレス 期間中、DHEA、テストステロン、DHEA + NE-100（ $\sigma$ 受容体 antagonist）を連日投与し、効果を検討した。性行動テストは発情脽を 尊入してから intromission至るまでの時間（intromission latency）および最初の intromissionから射精に至るまでの時間 （ejaculation latency）を観察した。各群で性行動テスト後に血清テ ストステロン、DHEA 值を測定した。結果りコントロール群に比し ストレス群では intromission latencyの有意な延長が認められ、血 清テストステロン、DHEA 值は有意に低下していた。DHEA、テス トステロン投与群では性行動は改善、DHEA+NE-100投与群では 改善は認められなかった。intromission を示した検体のみで比較す ると ejaculation latency においては各群に有意差は認められなかっ た。考察、結詥] DHEA は中枢神経に広く分布する $\sigma$ 受容体(抗不 安作用、ストレス楥衙作用に関与する)のリガンドのひとつであり、 DHEAが $\sigma$ 受容体を介して効果を発揮した可能性が示唆された。

\section{PP-676 動眽性勃起障害における海綿体組織障 害は早期から始まる}

\section{高松赤十字病院 泌尿器科}

中西 良一, 川西 泰夫, 布川 朋也, 甲藤 和伸, 山中 正人 小島 圭二, 沼田 明

【目的】動脈障害は灌流圧の低下だけではなく海綿体組織に障 害を与えると報告されている.手術を行った動脈性 ED 患者の 海綿体の組織学的, 薬理学的検討を行った. [対象と方法]偷理 委員会の承認を得て海綿体生検を行った. 对象は血管造影検查 と DICC 検查で確定診断された動脈性 ED7 例である. 血行再 建手術の際に生検を行った.コントロール群は問診上, 勃起機 能が正常な 6 例（陰茎腫序 4 例, 陰茎弯曲症 1 例, 陰茎折症 1 例)である．画像解析により平滑筋と膠原線維の面積比率を算 出した。また，Electrical field stimulation (EFS)による神経性 弛縟反応と内皮依存性弛緩反応を評価した. [結果】動脈性 ED 群の海綿体組織の平滑筋比率, 膠原線維比率はコントロール群 と同等であった。一方, 動脈性 ED 群では EFSによる池緩とア セチルコリンによる弛緩は有意に低下していた. [考察】これま での報告例と異なり DICC 検査が正常者な動脈性 ED を対象 としたので海綿体組織の形態的な差異を認めなかったと理解 される.しかしこのような对象においてもすでに神経依存性 弛縓反応と内皮依存性驰楥反応に障害が始まっていたことは 虚血による海綿体障害が比较的早期から始まることを示唆し ている. 虚血の程度や期間が関与すると想像されるが, 動脤性 EDに对してに早期の治㞠が必要であると思われる。 